\title{
Creativity in language learning and teaching: translingual practices and transcultural identities
}

Article

Accepted Version

Jones, R. H. (2020) Creativity in language learning and teaching: translingual practices and transcultural identities. Applied Linguistics Review, 11 (4). pp. 535-550. ISSN 18686311 doi: https://doi.org/10.1515/applirev-2018-0114 Available at https://centaur.reading.ac.uk/81519/

It is advisable to refer to the publisher's version if you intend to cite from the work. See Guidance on citing.

To link to this article DOI: http://dx.doi.org/10.1515/applirev-2018-0114

Publisher: De Gruyter

All outputs in CentAUR are protected by Intellectual Property Rights law, including copyright law. Copyright and IPR is retained by the creators or other copyright holders. Terms and conditions for use of this material are defined in the End User Agreement.

$\underline{\text { www.reading.ac.uk/centaur }}$ 
Central Archive at the University of Reading

Reading's research outputs online 


\title{
Creativity in language learning and teaching: \\ Translingual practices and transcultural identities
}

\author{
Rodney H. Jones \\ University of Reading
}

\begin{abstract}
This introduction explores the four main themes of the papers in this special issue: 1) 'language, languaging and translanguaging' 2) 'mobility and space' 3) 'transcultural identities' and 4) 'institutional and individual constraints on creativity', and discusses how engagement with these themes helps the authors to move beyond traditional notions of linguistic creativity and creative pedagogy to formulate new ways of imagining creativity in language learning based on encouraging learners to make use of the full range of their semiotic resources and social experiences when communicating.
\end{abstract}

\section{Introduction}

Most language educators would agree that language education should have something to do with 'creativity', whether that means that their teaching should be more creative, that they should use more 'creative texts' to teach with, or that they should inspire students to use language more 'creatively'. This consensus is no doubt the result of decades of promotion of the idea of 'creativity' from educational theorists (Pope, 2005; Sawyer et al, 2003), government bodies (Hall, 2010; Shaheen, 2010; UK Department of Education, 2014), professional organizations (National Council of Teachers of English \& International Reading Association, 1996), and business leaders (Amabile \& Khaire, 2008; World Economic Forum, 2016). What is often missing from these discussions of creativity and language learning, however, is a theoretically informed debate about what it really means to be a creative 
language user. Discussions tend to fall back on talk about how language use is 'inherently creative' (Chomsky, 1965; Jones, 2016), or about how bilinguals do better in standardized tests of creativity (Kharkhurin, 2009), or about the possible effects of creativity on learner motivation (Guilloteaux \& Dörnyei, 2008), or else they focus on the sharing of 'creative teaching ideas', often involving trendy new technologies (see for example Chow, Hui, \& Chui, 2018). Although such discussions certainly have merit, they sometimes suffer from the fact that they tend to construct the idea of creativity (and the idea of 'language' for that matter) in a vacuum, as an abstract quality of this or that technique or activity that can be easily slotted into any cultural context. In other words, with some notable exceptions (see for example Alim, 2007; Hafner, 2015), notions of creativity are often removed from the actual situations of people in the concrete physical and cultural spaces where they teach and learn, spaces where the idea of 'creativity' may be given lip service while at the same time being resisted or devalued (Coffey \& Leung, this issue; Robinson, 2007). In short, what is missing from most discussions of creativity and language education is an honest engagement with the 'messiness' of most situations in which people are trying to learn language, the 'messiness' of creativity, and the 'messiness' of the whole business of language itself (Jones, 2018).

How we understand creativity and its role in language learning and teaching is deeply tied up with how we understand language and the impact this way of understanding language can have on learners' identities and their sense of agency. Most considerations of creativity in language learning and teaching have taken place within the framework of dominant monolingual ideologies that see languages as discrete and abstract codes, separate from one another and from the messy social contexts in which they are used. As it turns out, it may be the very idea of 'language' itself (or at least 'named languages') that is the single factor working against the flourishing of creativity in language classrooms. 
This special issue of Applied Linguistics Review explores how our understandings of creativity and language learning can change when teachers and learners interrogate and challenge dominant understandings of language. It attempts to imagine what creativity in language teaching and learning might look like when teachers and learners start thinking outside of the 'box' of language. It also attempts to imagine how our ideas of language leaning might change if we were to treat creativity as if it really mattered, as if it were more than just a way to spice up a boring grammar lesson or a label that we give to some unexpectedly clever turn of phrase from a student. If we take seriously the idea that linguistic creativity involves not reproducing language but recreating, refashioning and recontextualizing linguistic and cultural resources (Maybin \& Swann, 2007), then we cannot help but see creativity as the deeply political act it is, as a way of shifting power relations among people, of contesting dominant discourses, and of reimagining new kinds of social identities and new ways of seeing the world (Jones, 2010).

In the first paper in this issue, Angelica Galante describes a series of activities she implemented with a group of international students in a Canadian university which encouraged them to recognize the range of linguistic resources they have available to them and to reimagine themselves as 'polylinguals'. The first step in encouraging creativity among learners, she argues, is to create the conditions in which all of their linguistic competencies and experiences are validated. The second paper, by Ron Darvin, presents a multimodal analysis of a YouTube adaptation of a play about migration by a group of students in the Philippines. Through his analysis, Darvin shows how the practices of translanguaging and transmediation that the project involved helped students develop a more critical understanding of migration and intercultural contact. In the third paper, Julie Choi describes the imaginative ways a pair of Japanese students in Australia created cultural spaces for themselves in an unfamiliar environment through various forms of multimodal 
performance art. The fourth paper, by Areej Albawardi and Rodney Jones, explores the ways young Saudi women use the translingual and multimodal affordances of Snapchat to negotiate new possibilities for self-expression and identity play within the constrains of conservative Saudi society. The final paper, by Simon Coffey and Constant Leung, examines how teachers' definitions of creativity can act to amplify or constrain learners' chances to engage creatively with language and exercise agency.

The papers in this special issue focus on four main themes relevant to creativity in language teaching and learning. The first: 'language, languaging and translanguaging' deals with how the conception of language held by teachers and learners influences the way they can respond creatively to the particular communicative challenges they face. In addressing this theme, authors draw heavily on the literature on translanguaging (e.g. Bradley, Moore, Simpson, \& Atkinson, 2018; Garcia \& Wei, 2013; Lewis, Jones, \& Baker, 2012; Li Wei, 2011), attempting to describe the interactional and social effects of trans and plurilingual pedagogies and how they can open up space for creativity. The second theme: 'mobility and space' interrogates this idea of 'space for creativity' and its relationship to what Li Wei (2011) calls 'translanguaging space'. Educational theory is full of spatial metaphors used to describe what's going on in students' minds (e.g. 'gaps in knowledge') or in institutional or sociocultural environments (e.g. 'third spaces') (Paechter, 2004), and the way 'translanguaging space' is discussed is often equally metaphorical. Several of the papers in this issue, however, (e.g. Albawardi and Jones, Choi, Darvin) focus as well on the importance of physical spaces and the role they play in the negotiation of translingual creativity. The third theme: 'transcultural identities' brings together the notions of translanguaging and mobility, exploring how translanguaging operates as a resource for learners to manage both their movement across national boundaries and their simultaneous existence in multiple cultural spaces with sometimes contradictory expectations about language use and social 
identity. The final theme which runs through these papers has to do with 'institutional and individual constraints on creativity', that is, how institutional definitions of creativity can conspire with the individual preconceptions of teachers and learners to constrain creativity and erode confidence, but also how creative practices both inside and outside the classroom can work to counter these forces.

\section{Language, Languaging and Translanguaging}

If there is one underlying implicit argument in all of the papers in the special issue it is that there is no such thing as 'creative language', and that constructions of some language, whether it be literary (Piat, 2006) or everyday (Carter, 2004), as 'creative' outside of the context in which it is used can actually interfere with fostering creativity in language learning, orienting teachers and learners towards a product-based view of creativity imbued with standards (regarding form or content) that they may believe are beyond their reach (see Coffey \& Leung, this issue). Rather, the authors of these papers promote a more processesbased view of creativity, one in which creativity lies not in texts or utterances, but in the actions of language users as they work to formulate linguistic (and non-linguistic) responses to specific moments of social interaction (Jones, 2010). This tendency to try to turn the dynamic and contingent processes of linguistic creativity into solid artefacts (texts) or formal attributes of language is, of course, not new. In part it comes from a broader tendency to see language itself as a kind of solid artefact defined by formal attributes. This formal, rule-based view of language, after all, is the basis for Chomsky's claim that that the grammatical rules of human language allow speakers to produce an infinite number of sentences, even sentences that have never been heard before.

A potent antidote to this way of describing language and linguistic creatively in the context of language teaching is Swain's (2006) notion of languaging, a word she came up with in her quest for a way to highlight the importance for language learners not of language 
per se, but of producing language. Swain's focus on language use rather than just language, to a large degree, has its roots in M.A.K. Halliday's (Halliday, 1978) challenge to Chomsky's formal view of language, which he proposed to replace with a model of language based on people's need to get along and to get things done in the social world. Within this model, meaning is not something that is conveyed through language. It is something that people make as they use language. Meanings do not exist in textbooks or dictionaries. They are created in concrete, situated moments of communication. From this perspective, creativity in language teaching partly involves resisting the idea that meanings are already 'known' and that the job of learners to simply reproduce them (Tin, 2013).

Swain's notion of languaging also has its roots in the work of Soviet psychologist Lev Vygotsky, whose sociocultural perspective on learning holds that learning is more of a social than a cognitive affair, a process of 'working things out' with others using the various 'cultural tools' available in the learner's social environment. Rather than passive vessels for knowledge, learners are active agents who learn by operating with whatever mediational means they have at hand (Jones, 2016; Wertsch, 1998). What this means when it comes to language learning is not just that people learn language through using language, but that they learn language through using language to learn about other things and to operate upon the world around them in meaningful ways. In this way, language is not just the residue of thought, it is a means through which thought and experience are transformed (Vygotsky, 1978; Wells, 1999).

This focus on agency and transformation also characterize later applications of the notion of languaging to language learning. In their book Modern Languages: Learning and Teaching in an Intercultural Field (2004), for example, Alison Phipps and Mike Gonzalez argue that languaging 'is at its core a question of agency, of individuals accumulating powers and understandings to enable them to become actively critical social beings' (p. 73). They 
quote Benson and Voller's (2014, p. 39) assertion that the whole point of using language is to engage in 'the struggle to become the author of one's own world, to be able to create one's own meanings, to pursue cultural alternatives amid the cultural politics of everyday life.' Jørgensen and his colleagues (Jørgensen, Karrebæk, Madsen, \& Møller, 2011) also emphasize the transformational power of languaging. 'Humankind is a languaging species,' they write' (p.23). 'This means that as human beings we use language to achieve our goals. Every time we use language, we change the world a little bit.'

Related to this focus on agency and transformation is the argument that languaging is also a central to self-knowledge and identity formation. If languaging is the means by which we create and change our worlds, it is also the means by which we create and change ourselves. 'An individual's capacity to know himself as an individual, his ability to develop a sense of self,' write Doughty and his colleagues, 'is a function of the capacity to language.' (Doughty, Thornton, \& Thornton, 1973, p. 61; see also Darvin \& Norton, 2015; Norton, 2000, 2013).

At the same time, in many discussions of languaging there comes something of a warning. Languaging is not likely to result from regimented classrooms where the furniture is neatly arranged into rows and the boundaries between right and wrong, work and play are clearly drawn. Languaging arises out of messiness, and often makes the world a messier place. 'It may be,' say Phipps and Gonzalaz (2004, p. 78), 'that creative disorder is a fundamental condition for languaging' (emphasis mine).

It is this challenging of boundaries and embrace of the fundamental messiness of actual language use (Canagarajah, 2012; Heller, 2007) that most characterize translanguaging, and related terms such as 'polylingual languaging' (Galente, this issue;, Jørgensen, 2008) 'metrolingualism' (Pennycook \& Otsuji, 2015), and 'transidiomatic practice' (Jacquemet, 2005). The most important boundary translanguaging challenges is that 
drawn between different 'named languages', a challenge that begins with the argument that languages themselves are 'inventions' (Heller, 2007; Makoni \& Pennycook, 2005), that rather than representing 'natural' entities in the minds of speakers, they are the result of social, cultural and political forces, particularly those associated with nationalism and colonialism. When it comes to the issue of creativity, what this breaking down of the artificial boundaries between languages means is that language users are empowered to make use of the full repertoire of linguistic resources they have available to them in their sociocultural environments to make meaning and take action in the world. As Otheguy and his colleagues (2015, p. 281) put it: 'Translanguaging is the deployment of a speaker's full linguistic repertoire without regard for watchful adherence to the socially and politically defined boundaries of named (and usually national and state) languages.' Taking a translingual perspective on creativity, however, involves not just going beyond 'languages', but also going beyond language to recognize how linguistic signs combine with non-linguistic signs such as gestures, images, clothing, the handling of objects and the use of the built environment (Rymes, 2013). Translanguaging, then, includes 'transmodality' and 'transmediation' (Darvin, this issue). This perspective is particularly important when considering how new tools of digital communication such as YouTube (Darvin, this issue) and Snapchat (Albawardi \& Jones, this issue) provide communicators with new ways to transverse, transform and transcend not just different linguistic systems but also different modes and media. Albarwadi and Jones, for example, argue that social media tools like Snapchat promote translingual epistomologies, encouraging users to combine different writing systems with different forms of graphic communication into sophisticated spatially arranged acts of communication.

The freedom to express oneself beyond the bounds of either languages or language, however, is not without constraints. The point of translanguaging is not that language users 
can do anything they want, but rather that they are able to bring to bear a wider range of resources to respond to the conventions and contingencies of whatever situation they find themselves in. Like languaging, translanguaging is about getting things done, and the measure of whether or not one is being successful is not some abstract notion of 'correctness', 'creativity' or 'cleverness', but rather the concrete, situated effectiveness of ones utterances. In other words, though the lens of translanguaging, linguistic creativity is about how language is used by learners to solve actual communicative problems in the real world.

The problems learners address through their translanguaging practices may be practical, personal, or interactional, but when their solutions involve challenging dominant ideas of language and the social structures and power relations that these ideas support, they also become political. Central to the notion of linguistic creativity promoted by the translanguaging model is that creativity is inseparable from criticality: to be creative necessarily involves recognizing how ideologies and power relations are constructed and reconstructed by the way we use language, as well as by the ways we are silenced. This relationship between criticality and creativity is evident, for example, in Darvin's description of how students in the Philippines creatively combine semiotic resources in their YouTube adaptation of a play about migration, challenging 'the boundaries of both word and world,' in Choi's description of how two Japanese exchange students in Sydney use their translingual practices to 'undo deeply ingrained cultural discourses and practices' that made them all but invisible in the cultural context in which they found themselves, in Galente's description of how international students in Canada struggle with the different ways they and others represent their linguistic repertories, and in Albarwardi and Jones's description of how young Saudi women creatively mix languages and other semiotic resources in their Snapchat stories to reflect upon and test the boundaries of gender conventions. As Davin (this issue) argues, 
'The creative capacity to represent meaning, through the assembly of linguistic and semiotic forms (translanguaging) across different media (transmediation) exists in a symbiotic relation with the critical capacity to interpret meaning, recognize ideologies embedded in texts, and challenge existing discourses.'

\section{Mobility and space}

One of the central tropes in Li Wei’s (2011) exploration of how translanguaging facilitates creativity and criticality is the trope of translanguaging space. The act of translanguaging, he argues, 'creates a social space for the multilingual user by bringing together different dimensions of their personal history, experience and environment, their attitude, belief and ideology, their cognitive and physical capacity into one coordinated and meaningful performance' (p. 1223). This idea of translanguaging space is complex and multilayered, involving individual, social, symbolic and material dimensions. It is both intensely personal and 'located in a wider social space', both cultural and beyond culture, both 'constructed in specific socio-historical conditions' and transcending those conditions, spanning space and time. 'The boundaries of translanguaging space,' writes Li Wei (2011, p. 1223), 'are ever shifting; they exist primarily in the mind of the individual who creates and occupies it, and the construction of the space is an ongoing, lifelong process.'

Li Wei (2011, p. 1223) invokes the work of the French sociologist Heri Lefebvre (1991) to help explain these complexities. According to Lefebvre, social space is produced through the interaction of three kinds of spaces: 1) 'perceived space' (or 'spatial practices'), which consists of the choices we make within the physical spaces we inhabit, where we choose to go, how we choose to stand, whom we choose to interact with; 2) 'representational' or 'lived' space, the way we experience the spaces we inhabit, the meanings we imbue them with based on our past experiences, or, in Lefevbre's (1991, p. 39) words, 'the passively 
experienced space, which the imagination seeks to change and appropriate'; and 3)

'represented' or 'conceived' space, the way space is 'supposed to be' and the ways ideologies and relations of power are built into physical and social spaces (traditional classrooms with their panoptical arrangement of desks are a good example). Not surprisingly, these three kinds of space don't always fit comfortably together; in fact, Lefevbre, good Marxist that he is, sees the relationship between these spaces as dialectical, the production of space inevitably the result of a working out of contradictions between what people do with space, how they experience it, and how others want them to use it.

This working out of contradictions is particularly evident in the tales of space and mobility described in the papers in this special issue, tales of people who find themselves 'out of place', whose experience of space is characterized by movement across national boarders as well as across a range of cultural boundaries in their everyday lives. As with all mobilities, these movements present inevitable challenges as people find that different resources in their linguistic repertoires are valued differently in different geographical and social spaces (Blommaert, 2010).The Japanese students in Choi's paper, for example, struggle to find ways to carve out spaces within which to express their identities in the unfamiliar cultural landscape of Australia, Galente's EAP students in Canada seek for spaces in which the cultural and linguistic practices they have brought with them from other countries can be honoured, and the female Saudi university students described by Albawardi and Jones search for spaces where they can be both modern and traditional, both Saudi and international.

In all of these cases, languaging, or rather, translanguaging plays a central role in resolving these contradictions. But this is also the case in Lefebvre's model. In fact, it might be argued that the contradictions among the three kinds of space he describes is crucially worked out through the production of a fourth space: the 'space of speech'. Lefevbre (1991, p. 403) writes: 
There is a space of speech whose prerequisites, as we have seen, are the lips, the ears, the ability to articulate, masses of air, sounds, and so on. This is a space, however, for which such material preconditions are not an adequate definition: a space of actions and of inter-actions, of calling and of calling back and forth, of expressiveness and power, and already at this level - of latent violence and revolt; the space, then, of a discourse that does not coincide with any discourse on or in space. The space of speech envelops the space of bodies and develops by means of traces, of writings, of prescriptions and inscriptions.

This space of speech that Lefebvre describes is an inevitably messy space, one which both envelopes bodies and physical spaces and develops through traces left by previous speakers and writers (in the form of texts) and trajectories towards future possibilities of speaking.

The aspect of Lefevbre's model that is perhaps least developed in Li Wei's application is the embodied nature of traslanguaging space, the fact that that languaging is always to some extent a spatial practice of the body (Bucholtz \& Hall, 2016) which not only presupposes 'the use of the body: the use of the hands, members and sensory organs, and the gestures of work as of activity unrelated to work,' but also of 'representations of the body', both those produced by others 'derived from accumulated scientific knowledge, disseminated with an admixture of ideology' and those we produce of our own bodies and our lived experiences with and through them' (Lefebvre, 1991, p. 40).

An engagement with this embodied dimension of translanguaging space - the ways physical spaces are transformed by the affective ways we deploy our bodies (Blackman, 2012), and the ways linguistic practices are inevitably tied up with how we represent our bodies-- is perhaps one of the most significant contributions of this special issue. It is a theme most evident in the papers by Choi -- who describes how the Japanese students she studies 
mobilized their bodies by dressing them in unconventional clothing and arranging them in unconventional poses in front of iconic buildings to confront the feelings of fear and shame they associated with languaging in an unfamiliar environment - and Albawardi and Jones who examine how young Saudi women on Snapchat use images of their bodies inhabiting specific physical and cultural spaces as both a resource for making meaning (Jones, in press) and a 'canvass' upon which to experiment with different kinds of linguistic signs. Central to the argument of Albawardi and Jones is the idea of emplacement, the notion that one key to understanding the creative potential of translanguaging is understanding how people make meaning through strategically placing semiotic resources within different physical and textual spaces, which include:

the physical space where photos are taken, the screen space of the app which functions as a canvas for the arrangement of different kinds of semiotic objects (photos, text, writing, drawing, emojis), the phenomenological space communicated through the embodied perspectives of users as they experience different physical spaces (what we are calling embodied space), relational space, formed through the interpersonal relationships created between the sender and the receiver of messages, and cultural space, formed through the invocation of different 'discourse systems'. 'Key to the communicative affordances of (digital) technologies,' Albarwardi and Jones contend, 'are the ways they allow users to move between, mix and link together different physical spaces, in the same way multilinguals move between, mix and transcend semiotic systems, personal histories, identities and practices.'

\section{Transcultural identities}

For Lefebvre, social spaces are almost always sites of struggle over the physical form they will take, over how they are represented, and, most of all, over the kinds of cultural 
meanings they make possible for their inhabitants. This is particularly true of translanguaging space, which Li Wei (2011, p. 1223), characterizes as 'a space where the process of what Bhabba (1994) calls "cultural translation" between traditions takes place; it is not a space where different identities, values and practices simply co-exist, but combine together to generate new identities, values and practices.' In other words, what the production of translanguaging space potentially acheives for learners is the opportunity to creatively forge for themselves new 'transcultural identities'.

Of course, the idea of interculturality is not new to language learning. Languaging, according to Phipps and Gonzalez (2004, pp. 167-168), always has the potential to open 'us out as people who are always in the process of becoming intercultural beings, whose whole lives are a patchwork of cultural colours, who respect and understand and engage openly with the different ways of living life and understanding the world that we may encounter in others and in ourselves.' The notion of 'transcultural identities' as illustrated in the papers in this issue, however, is something rather different. It is, as Li Wei says, not just about the ability to combine different cultures together; it is, in fact, not about the ability to reproduce cultures at all, but rather about the possibility of recreating them. It is not just about 'appreciating others' and 'engaging with different ways of living life', but also about confronting the messy, uncomfortable, and sometimes even oppressive ways that cultures combine in our social worlds and in ourselves. As Choi (this issue) puts it, 'Making oneself understood in another language is not simply a matter of learning the words and concepts but entails breaking free from a long history of being stubbornly attached to certain cultural discourses and practices.'

Transcultural identities never just happen; they are the result of intense practices of negotiation around linguistic and cultural representations, and around the different social values that come to be attached to different semiotic resources. Ultimately they are about 
pushing back against the monolingual bias that partial competence with and unbalanced access to different linguistic and cultural resources — what Blommaert (2010) calls 'truncated resources' - is a sign of a deficiency rather than creativity and adaptability

Transcultural identities are also not just a characteristic of intercultural encounters, such as those described by Choi and Galente, but are also part of intracultural encounters, as people use languaging to attempt to reconcile the sometimes contradictory demands of local cultures and their simultaneous membership in multiple 'discourse systems' (Scollon, Scollon, \& Jones, 2012), including gender, generational and professional discourse systems. This is particularly evident in the case of the Albarwardi and Jones's examination of the ways young Saudi women mix communicative resources in order to negotiate different cultural spaces in their societies, reconciling, for example the demands of being highly educated members of digitally savey youth culture with more traditional constraints on their gender performances. But it is also evident the Coffey and Leung's interviews about creativity with language teachers, who must continually navigate through sometimes incommensurate professional, institutional and personal expectations about how to be 'creative' teachers.

All of these enactments of transcultural identities are examples of what Li Wei (2016) calls the 'post multilingual challenge' of having to express one's cultural values (be they values associated with regional, religious, gender or professional cultures) using a range of semiotic resources, some of which come from 'other' cultures, including the culture of one's 'enemies' or 'rivals'. This is a challenge that is not just faced buy language learners and teachers, but also by politicians, professionals, parents, and anyone else who finds themselves operating in today's increasingly superdiverse communities.

\section{Institutional and individual constraints on creativity}


The final theme that runs through the papers in this issue is the fact that, despite the clear social and pedagogical benefits for learners in engaging in translingual, transmodal and transmedial acts of creativity, there exist considerable obstacles to them doing so from the societies in which they live and the institutions in which they learn. Although these constraints on creativity linger in the background of all of the papers, they constitute the main theme of the paper by Coffey and Leung, which is somewhat of an outlier in this issue in that it takes the teacher's perspective rather than the perspective of learners characteristic of the other papers. In this way, though, it functions as a useful counterweight to the other papers, providing not just an alternative perspective but also a 'reality check' about the kinds of discursive debates that frame teachers' and learners' experiences of creativity in schools.

What Coffey and Leung attempt to do in their paper is formulate a broader argument about how creativity in language learning is shaped by socio-historical, institutional and ideological factors, and how the resultant discursive constructions of creativity determine how teachers and learners are able to position themselves and exercise agency in relation to the dominant discourses in their societies. While they encounter a wide range of perspectives in their interviews with teachers about creativity, many of these are marred by skepticism about whether learners, especially less proficient learners, are capable of linguistic creativity or whether or not creative pedagogy can be successfully reconciled with the tight demands of structured curricula or students' and parents' expectations about what constitutes academic achievement. As with the other papers in this issue, people's conceptions of what it means to be creative are intimately tied up with their understanding of what language is and of what it means to be a person. In most EFL settings, Coffey and Leung observe, the 'functional orientation to language teaching and learning constrains the conception of creativity toward an understanding of creative pedagogy rather than creative language.' To get beyond the constraints of this functional orientation, they argue, will require a kind of shift in focus not 
very different from the shift from a focus on language to a focus on socially situated and affectively grounded (trans)languaging demonstrated in the other papers in the issue, a shift, as Coffey and Leung put it, 'from a focus on personal, psychological motivation toward framing learning as a social practice, and from learning as a mainly intra-individual cognitive process to a broader understanding of learning as involving socially connected emotion, identity and embodiment.'

This shift will, as Coffey and Leung suggest, not come though concentrating on 'creative pedagogy' alone; it can only result from changing our ideas about what we mean by 'creative language', and perhaps getting away from the notion of creative language althogether and staring to think more in terms of 'creative languaging'. It will not come about through training teachers to be more creative in their teaching, but from training them to recognize the range of resources students have available to them to solve the real world communication problems that confront them themselves. As Stevick (1980, p. 20) puts it, 'we should judge creativity in the classroom by what the teacher makes possible for the student to do, not just by what the teacher does.'

Interestingly, Stevick, back in the early 1980s associated creativity with the concept of 'learning space' - the idea that creativity will naturally flourish if teachers give students enough 'space' to develop and express themselves. Nearly forty years later, in this issue, we are suggesting a new kind of space associated with linguistic creativity, namely translanguaging space. This, however, is a very different kind of space described by Stevick. It is not a space that teachers can provide for learners, but one that learners need to create for themselves. It is not a space of 'freedom', but rather one of negotiation in which the real world constraints of linguistic, racial, gender and economic domination are not swept under the rug. In other words, it is not the warm of comfortable space of a 'greenhouse' where our students' creativity will 'naturally' flourish and grow, but rather a space that is more like a 
marketplace, with all of its colours and contradictions, possibilities and dangers, a space in which creative practices and transcendent identities are born from moment by moment acts of negotiating the messiness inherent in our social worlds.

\section{References}

Alim, H. S. (2007). Critical Hip-Hop Language Pedagogies: Combat, Consciousness, and the Cultural Politics of Communication. Journal of Language, Identity \& Education, 6(2), 161-176. https://doi.org/10.1080/15348450701341378

Amabile, T., \& Khaire, M. (2008, October 1). Creativity and the Role of the Leader. Harvard Business Review, (October 2008). Retrieved from https://hbr.org/2008/10/creativityand-the-role-of-the-leader

Benson, P., \& Voller, P. (2014). Autonomy and Independence in Language Learning. London: Routledge.

Bhabha, H. K. (1994). The Location of Culture. London: Routledge.

Blackman, L. (2012). Immaterial Bodies: Affect, Embodiment, Mediation. Thousand Oaks, CA: SAGE.

Blommaert, P. D. J. (2010). The Sociolinguistics of Globalization (1 edition). Cambridge, UK ; New York: Cambridge University Press.

Bradley, J., Moore, E., Simpson, J., \& Atkinson, L. (2018). Translanguaging space and creative activity: Theorising collaborative arts-based learning. Language and Intercultural Communication, 18(1), 54-73. https://doi.org/10.1080/14708477.2017.1401120

Bucholtz, M., \& Hall, K. (2016). Embodied sociolinguistics. In N. Coupland (Ed.), Sociolinguistics (pp. 173-198). Cambridge: Cambridge University Press. https://doi.org/10.1017/CBO9781107449787.009 
Canagarajah, S. (2012). Translingual Practice: Global Englishes and Cosmopolitan Relations. Milton Park, Abingdon, Oxon; New York: Routledge.

Carter, R. (2004). Language and creativity: The art of common talk. New York: Routledge. Chomsky, N. (1965). Aspects of the theory of syntax. MIT Press.

Chow, B. W.-Y., Hui, A. N. N., \& Chui, B. H.-T. (2018). Creative literacy activities promote positive reading attitude in children learning English as a foreign language. Journal of Research in Reading, 41(2), 278-289. https://doi.org/10.1111/1467-9817.12096

Darvin, R., \& Norton, B. (2015). Identity and a Model of Investment in Applied Linguistics. Annual Review of Applied Linguistics, 35, 36-56. https://doi.org/10.1017/S0267190514000191

Doughty, P. S., Thornton, G. M., \& Thornton, G. (1973). Language Study: The Teacher and the Learner. London: Hodder.

Garcia, O., \& Li, W. (2013). Translanguaging: Language, Bilingualism and Education. Palgrave Pivot.

Guilloteaux, M. J., \& Dörnyei, Z. (2008). Motivating Language Learners: A ClassroomOriented Investigation of the Effects of Motivational Strategies on Student Motivation. TESOL Quarterly, 42(1), 55-77. https://doi.org/10.1002/j.15457249.2008.tb00207.x

Hafner, C. A. (2014). Embedding Digital Literacies in English Language Teaching: Students' Digital Video Projects as Multimodal Ensembles. TESOL Quarterly, 48(4), 655-685. https://doi.org/10.1002/tesq.138

Hafner, C. A. (2015). Remix Culture and English Language Teaching: The Expression of Learner Voice in Digital Multimodal Compositions. TESOL Quarterly, 49(3), 486509. https://doi.org/10.1002/tesq.238 
Hall, C. (2010). Creativity in recent educational discourse in England. World Englishes, 29(4), 481-492.

Halliday, M. A. K. (1978). Language as social semiotic: The social interpretation of language and meaning. London: Edward Arnold.

Heller, M. (2007). Bilingualism as Ideology and Practice. In M. Heller (Ed.), Bilingualism: A Social Approach (pp. 1-22). London: Palgrave Macmillan UK. https://doi.org/10.1057/9780230596047_1

Jacquemet, M. (2005). Transidiomatic practices: Language and power in the age of globalization. Language \& Communication, 25(3), 257-277. https://doi.org/10.1016/j.langcom.2005.05.001

Jones, R. H. (2010). Creativity and discourse. World Englishes, 29(4), 467-480. https://doi.org/10.1111/j.1467-971X.2010.01675.x

Jones, R. H. (2016). Creativity and language. In R. H. Jones \& J. C. Richards (Eds.), Creativity and language teaching: Perspectives from research and practice (pp. 1631). London: Routledge.

Jones, R. H. (2018). Messy creativity. Language Sciences, 65, 82-86. https://doi.org/10.1016/j.langsci.2017.06.003

Jones, R.H. (in press). Towards and embodied visual semiotics. in C. Thurlow, C. Dürscheid \& F. Diemoz (eds.). Visualizing (in) the New Media. Berlin: De Gruyter.

Jørgensen, J., Karrebæk, M. S., Madsen, L. M., \& Møller, J. S. (2011). Polylanguaging in Superdiversity. Diversities, 13(2), 23-37.

Jørgensen, J. N. (2008). Polylingual Languaging Around and Among Children and Adolescents. International Journal of Multilingualism, 5(3), 161-176. https://doi.org/10.1080/14790710802387562 
Kharkhurin, A. V. (2009). The Role of Bilingualism in Creative Performance on Divergent Thinking and Invented Alien Creatures Tests. The Journal of Creative Behavior, 43(1), 59-71. https://doi.org/10.1002/j.2162-6057.2009.tb01306.x

Lefebvre, H. (1991). The production of space. Oxford: Basil Blackwell.

Lewis, G., Jones, B., \& Baker, C. (2012). Translanguaging: origins and development from school to street and beyond. Educational Research and Evaluation, 18(7), 641-654. https://doi.org/10.1080/13803611.2012.718488

Li Wei. (2011). Moment Analysis and translanguaging space: Discursive construction of identities by multilingual Chinese youth in Britain. Journal of Pragmatics, 43(5), 1222-1235. https://doi.org/10.1016/j.pragma.2010.07.035

Li Wei (2016). New Chinglish and the Post-Multilingualism challenge: Translanguaging ELF in China. Journal of English as a Lingua Franca, 5, 1-25.

Makoni, S., \& Pennycook, A. (2005). Disinventing and (Re)Constituting Languages. Critical Inquiry in Language Studies, 2(3), 137-156.

Maybin, J., \& Swann, J. (2007). Everyday creativity in language: textuality, contextuality and critique. Applied Linguistics, 28(4), 497-517.

National Council of Teachers of English, \& International Reading Association (Eds.). (1996). Standards for the English language arts. Newark, Del. : Urbana, Ill: International Reading Association ; National Council of Teachers of English.

Norton, B. (2000). Identity and Language Learning: Gender, Ethnicity and Educational Change. Longman.

Norton, B. (2013). Identity and Language Learning: Extending the Conversation (2 edition). Bristol: Multilingual Matters. 
Otheguy, R., García, O., \& Reid, W. (2015). Clarifying translanguaging and deconstructing named languages: A perspective from linguistics. Applied Linguistics Review, 6(3). https://doi.org/10.1515/applirev-2015-0014

Paechter, C. (2004). Metaphors of space in educational theory and practice. Pedagogy, Culture \& Society, 12(3), 449-466. https://doi.org/10.1080/14681360400200202

Pennycook, A., \& Otsuji, E. (2015). Metrolingualism: Language in the City. London: Routledge.

Phipps, A., \& Gonzalez, M. (2004). Modern Languages: Learning and Teaching in an Intercultural Field. SAGE.

Piat, J. (2006). Towards a Stylistics of Imaginary Languages. Corpus, 5(Dec), 113-141.

Pope, R. (2005). Creativity: Theory, history and practice. London: Routledge.

Robinson, K. (2007, January 6). Do Schools Kill Creativity? Retrieved 3 November 2018, from https://www.youtube.com/watch?v=iG9CE55wbtY

Rymes, B. (2013). Communicating Beyond Language (1 edition). New York ; London: Routledge.

Sawyer, R. K. (2003). Creativity and Development.

Scollon, R., Scollon, S. W., \& Jones, R. H. (2012). Intercultural communication: A discourse approach (3rd ed.). Chichester: Wiley-Blackwell.

Stevick, E. W. (1980). Teaching Languages: A Way and Ways (1st Edition edition). Boston: Heinle \& Heinle Pub.

Swain, M. (2006). Languaging, Agency and Collaboration in Advanced Second Language Proficiency. In H. Byrnes (Ed.), Advanced Language Learning: The Contribution of Halliday and Vygotsky (pp. 95-108). London-New York: Continuum.

Tin, T. B. (2013). Towards creativity in ELT: The need to say something new. English Language Teaching Journal, 67(4), 385-397. 
UK Department of Education. (2014). National curriculum in England: framework for key stages 1 to 4 . Retrieved 13 November 2018, from https://www.gov.uk/government/publications/national-curriculum-in-englandframework-for-key-stages-1-to-4/the-national-curriculum-in-england-framework-forkey-stages-1-to-4

Vygotsky, L. S. (1978). Mind in Society: The Development of Higher Psychological Processes. (M. Cole, V. John-Steiner, S. Scribner, \& E. Souberman, Eds.) (Revised ed.). Cambridge, Mass.: Harvard University Press.

Wertsch, J. (1998). Mind as Action. New York: Oxford University Press.

World Economic Forum. (2016). The Future of Jobs Employment, Skills and Workforce Strategy for the Fourth Industrial Revolution. Davos: WEF. 